CORRECTION

\title{
Correction: Functional abnormalities in induced Pluripotent Stem Cell-derived cardiomyocytes generated from titin-mutated patients with dilated cardiomyopathy
}

\section{The PLOS ONEStaff}

In the Author Contributions section, Michaela Gherghiceanu (MG) should have the contribution "Formal analysis" instead of "Resources".

The following information is missing from the Funding section: This study was supported by the Rappaport Family Institute for Research in the Medical Sciences [grant number 015.03$01]^{\prime \prime}$.

The publisher apologizes for the errors.

\section{Reference}

1. Schick R, Mekies LN, Shemer Y, Eisen B, Hallas T, Ben Jehuda R, et al. (2018) Functional abnormalities in induced Pluripotent Stem Cell-derived cardiomyocytes generated from titin-mutated patients with dilated cardiomyopathy. PLoS ONE 13(10): e0205719. https://doi.org/10.1371/journal.pone.0205719 PMID: 30332462

G open Access

Citation: The PLOS ONEStaff (2018) Correction: Functional abnormalities in induced Pluripotent Stem Cell-derived cardiomyocytes generated from titin-mutated patients with dilated cardiomyopathy. PLOS ONE 13(11): e0207548. https://doi.org/ 10.1371/journal.pone.0207548

Published: November 8, 2018

Copyright: @ 2018 The PLOS ONE Staff. This is an open access article distributed under the terms of the Creative Commons Attribution License, which permits unrestricted use, distribution, and reproduction in any medium, provided the original author and source are credited. 